\title{
STUDI LITERATUR PENGARUH KONDISI RUMAH YANG KUMUH TERHADAP KEJADIAN PENDERITA TUBERKULOSIS (TB) PARU
}

\author{
Clarisa Rahmah ${ }^{1}$ \\ ${ }^{1}$ Program Pendidikan Dokter, Fakultas Kedokteran Universitas Lampung
}

\begin{abstract}
Literature Review : The Effect of a Slummed House Condition on the Events of Tuberculosis (TB) Patient. Indonesia is a country with the second highest pulmonary tuberculosis (TB) disease in the world. TB is a major public health problem with the number of TB patients in Indonesia second only to India following China, the Philippines and Pakistan. Tuberculosis (TB) is an inflammatory lung disease caused by infection with the TB bacteria, namely Mycobacterium tuberculosis. The most common symptoms of TB disease are cough with phlegm that lasts for more than two weeks, chest pain, systemic symptoms (fever, malaise, night sweats, and anorexia). TB spreads through the patient's droplet nuclei, so everyone who has TB has a risk for infection, especially household contacts with pulmonary TB sufferers. Environmental conditions in the house that do not meet the requirements become a transmission medium for pulmonary tuberculosis. Environmental factors in the house associated with the incidence of pulmonary tuberculosis are room ventilation, room humidity, sunlight, room occupancy density. A slum and dense environment will make TB transmission take place quickly. TB disease can be prevented by breaking the chain of transmission, namely by treating TB sufferers until they are completely cured and by implementing a clean and healthy lifestyle. A healthy environment and maintaining cleanliness by not spitting anywhere, using a closed place for sputum, not dumping sputum anywhere, and adopting clean and healthy living habits are important things to do in preventing the transmission of TB disease.
\end{abstract}

Keywords : Prevention, Risk Factors, Slum Houses, Transmission, Tuberculosis

Abstrak: Indonesia merupakan negara dengan peringkat kedua kasus penyakit tuberkulosis (TB) Paru tertinggi di dunia. TB merupakan masalah utama kesehatan masyarakat yang dengan jumlah pasien TB di Indonesia merupakan kedua terbanyak setelah India menyusul China, Philipina, dan Pakistan. Penyakit Tuberkulosis (TB) adalah penyakit radang parenkim paru yang bersifat menular disebabkan oleh infeksi bakteri TB yaitu Mycobacterium tuberculosis. Gejala penyakit TB yang paling sering yaitu batuk berdahak yang berlangsung selama lebih dari dua minggu, nyeri dada, sesak nafas disertai gejala sistemik (demam, malaise, keringat malam, dan anoreksia). TB menyebar melalui droplet nuclei penderita, sehingga setiap orang yang kontak dengan penderita TB memiliki risiko untuk terinfeksi, terutama kontak serumah penderita TB paru. Kondisi lingkungan dalam rumah yang tidak memenuhi syarat menjadi media penularan penyakit TB paru. Faktor lingkungan dalam rumah yang berhubungan dengan kejadian penyakit TB paru adalah ventilasi kamar, kelembaban kamar, sinar matahari, dan kepadatan hunian kamar. Lingkungan yang kumuh dan padat akan membuat penularan TB berlangsung cepat. Penyakit TB dapat dicegah dengan memutuskan rantai penularan yaitu dengan mengobati penderita TB sampai benar-benar sembuh serta dengan melaksanakan pola hidup bersih dan sehat. Lingkungan yang sehat serta menjaga kebersihan dengan tidak meludah di sembarang tempat, menggunakan tempat yang tertutup untuk menampung dahak, tidak membuang dahak di sembarang tempat, dan menerapkan perilaku hidup bersih dan sehat merupakan hal yang penting untuk dilakukan dalam mencegah penularan penyakit TB.

Kata Kunci : Pencegahan, Faktor Resiko, Rumah Kumuh, Penularan, Tuberkulosis 


\section{PENDAHULUAN}

Indonesia merupakan negara dengan peringkat kedua kasus penyakit tuberkulosis (TB) Paru tertinggi di dunia. Lima negara dengan insiden kasus tertinggi yaitu India, Indonesia, China, Philipina, dan Pakistan (Infodatin, 2018). Pada tahun 2016 penderita TB Paru mengalami peningkatan dari tahun sebelumnya dari 9,6 juta jiwa menjadi 10,5 juta jiwa. Angka ini cenderung mengalami peningkatan dibandingkan dengan jumlah penderita TB paru BTA $(+)$ tahun 2010 adalah sekitar 302.861 orang, di mana 183.366 kasus di antaranya adalah menderita BTA (+) (Butarbutar, 2018). World Health Organization (WHO) menyatakan bahwa TB merupakan salah satu dari 10 penyebab utama kematian akibat penyakit infeksi. TB menyebabkan sekitar 1,3 juta kematian dan terdapat 6,4 juta kasus baru TB yang dilaporkan pada tahun 2017 di seluruh dunia (WHO, 2017).

Pada tahun 2016 di Indonesia terdapat 298 ribu penemuan kasus TB Paru dan 156 ribu penemuan kasus BTA (+) berdasarkan hasil cakupan penemuan kasus penyakit TB Paru. Hasil riset Kementerian Kesehatan Republik Indonesia 2018, menyebutkan bahwa jumlah prevalensi Tuberkulosis paru klinis yang tersebar di seluruh Indonesia yaitu $1,0 \%$. Beberapa Provinsi yang di antaranya mempunyai angka Prevalensi di atas angka Nasional yaitu: Provinsi Aceh, DKI Jakarta, Daerah Istimewa Yogyakarta, Sumatra barat, kepulauan Riau, Nusa Tengara Barat, Nusa Tengara Sulawesi selatan, Sulawesi tengah dan daerah timur Indonesia (Riskesdas, 2018).

Pemerintah telah mencanangkan konsep pembangunan kesehatan menuju Indonesia sehat (2015 - 2025) yang bertujuan untuk meningkatkan kesadaran, kemauan dan kemampuan hidup bagi setiap orang agar terwujud derajat kesehatan masyarakat yang optimal. Melalui berbagai program kesehatan salah satunya mengeksekusi penyakit menular akibat infeksi pernafasan yaitu TB paru. Pemerintah Indonesia melalui Kementerian Kesehatan membuat sasaran strategis pengendalian TB hingga 2014 mengacu pada rencana strategis yaitu menurunkan prevalensi TB dari 235 per 100.000 penduduk menjadi 224 per 100.000 penduduk (Infodatin, 2015). Sejak tahun 2016, tujuan program TB Paru adalah mengakhiri epidemik TB Paru melalui penerapan strategi End TB. Strategi tersebut berupa mengurangi kematian akibat TB Paru sebesar $90 \%$ pada tahun 2030 dan memutuskan kejadian kasus baru TB sebesar $80 \%$ (WHO, 2015).

Penyakit Tuberkulosis (TB) adalah penyakit radang parenkim paru yang bersifat menular disebabkan oleh infeksi bakteri TB yaitu Mycobacterium tuberculosis (CDC, 2016). Sebagian besar kuman TB menyerang paru tetapi dapat juga mengenai organ tubuh lain (Janan $M$, 2019). Penderita tuberkulosis paru BTA (+) dapat menularkan pada orang sekelilingnya, terutama yang melakukan kontak erat. Setiap penderita tuberculosis paru BTA (+) dapat menularkan pada 1015 orang per tahun. Daya penularan dari seorang penderita TB paru BTA (+) ditentukan oleh banyak bakteri yang dikeluarkan dari paru-paru. Pada saat penderita mengalami batuk dan bersin maka bakteri penyebab penyakit TB akan ditularkan melalui udara dalam bentuk percikan dahak. Apabila penderita mengalami batuk dan bersin dalam suatu ruangan yang tertutup maka akan memudahkan proses penularan TB yang akan menghasilkan kurang lebih 3000 percikan. TB menyebar melalui droplet nuclei penderita, sehingga setiap orang yang kontak dengan penderita TB memiliki risiko untuk terinfeksi, terutama kontak serumah penderita TB paru. Penularan penyakit TB pada kontak serumah dapat terjadi karena perilaku penderita TB paru yang menyebabkan kontaminasi bakteri TB di udara dalam rumah, seperti batuk dan bersin tanpa menutup mulut (Muslimah, 2019).

Kondisi lingkungan dalam rumah yang tidak memenuhi syarat menjadi media penularan penyakit TB paru. Rumah atau tempat tinggal yang buruk atau kumuh dapat mendukung terjadinya penularan penyakit dan gangguan kesehatan seperti TB Paru. Faktor lingkungan dalam rumah yang secara 
statistik berhubungan bermakna dengan kejadian penyakit TB paru adalah ventilasi kamar, kelembaban kamar, sinar matahari, dan kepadatan hunian kamar (Versitaria dan Kusnoputranto, 2011). Faktor risiko yang mempengaruhi kejadian TB di antaranya adalah lingkungan terkait dengan pencahayaan rumah, kelembapan, suhu, kondisi atap, dinding, lantai rumah serta kepadatan hunian (Azhar K dan Perwitasari D, 2014). Lingkungan rumah yang kurang sehat dapat mempengaruhi tingginya kejadian TB paru misalnya kurang adanya fasilitas ventilasi yang baik, pencahayaan yang buruk di dalam ruangan, kepadatan hunian dalam rumah dan bahan bangunan di dalam rumah (Asrijun, 2018). Maka dari itu pencegahan penularan penyakit TB paru dapat dilakukan dengan mengetahui faktor-faktor yang mempengaruhi penularan penyakit TB, terutama pada kontak serumah penderita sehingga dapat dijadikan dasar upaya pencegahan penularan dan penyebaran penyakit TB paru.

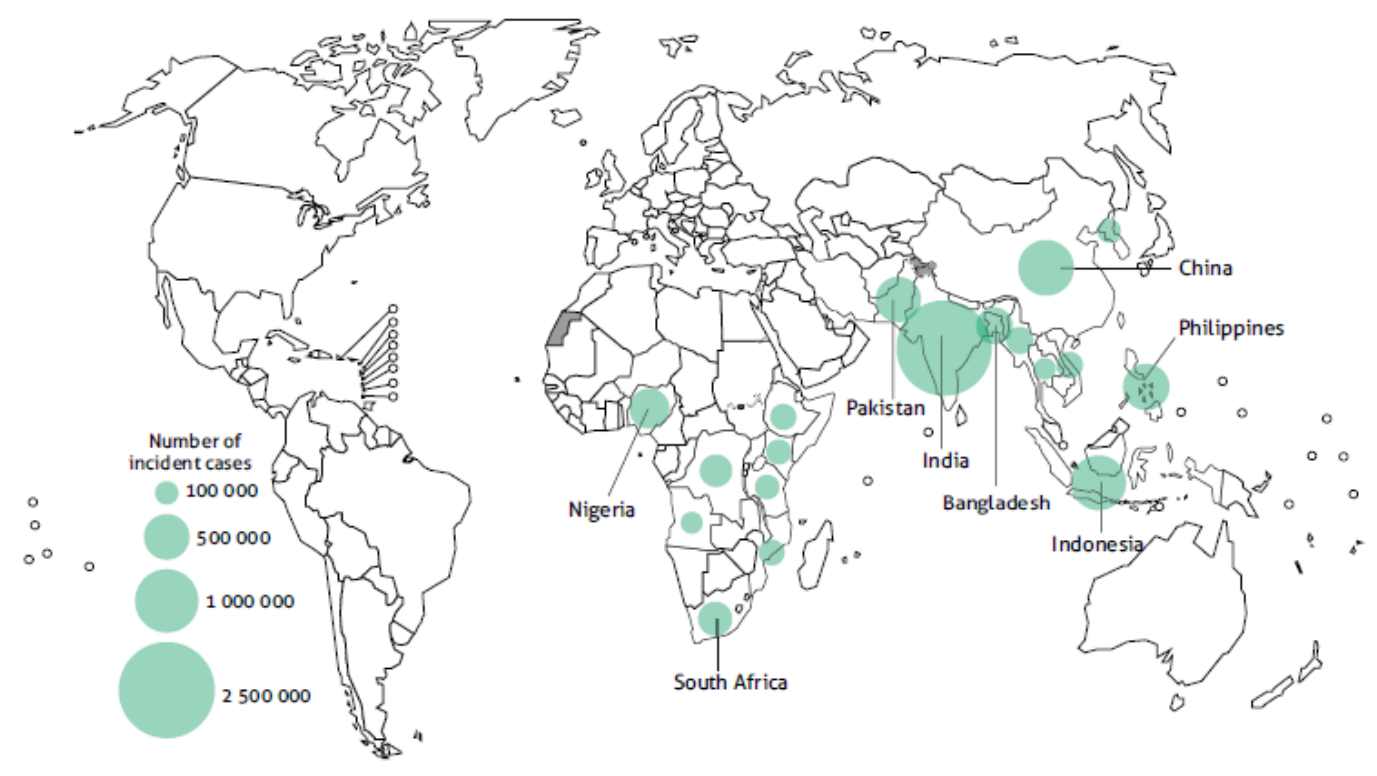

Gambar 1. Pola penyebaran kasus TB di dunia Tahun 2018 (WHO, 2019)

\section{METODE}

Metode yang digunakan dengan mengumpulkan data sekunder yang sudah tertera pada sitasi dan daftar pustaka.

\section{HASIL}

Penyakit TB Paru berkembang pesat pada orang yang hidup dalam kemiskinan, kelompok terpinggirkan, dan populasi rentan lainnya. Kepadatan penduduk di Indonesia sebesar 136,9 per km2 dengan jumlah penduduk miskin pada September 2017 sebesar 10,12\% (Infodatin, 2018). Penelitian yang dilakukan oleh Muslimah, 2019 menyatakan terdapat hubungan antara lingkungan fisik dengan keberadaan Mycobacterium tuberculosis di udara ruangan tempat berkumpul terdapat pada suhu, kelembapan dan pencahayaan. Penelitian ini menemukan bahwa faktor lingkungan rumah yang terdiri dari pencahayaan, kelembapan, kondisi atap, dinding dan lantai signifikan berhubungan dengan kejadian penyakit TB dan kepadatan hunian menjadi faktor yang paling berpengaruh terhadap kejadian penyakit tersebut. Slum area menjadi area yang berpotensi untuk menjadi wilayah penyebaran penderita TB dengan keberadaan faktor-faktor lingkungan tersebut.

Hal ini sejalan dengan penelitian yang dilakukan oleh Asrijun (2018) menyatakan bahwa faktor pencahayaan merupakan faktor risiko yang cukup signifikan karena cahaya matahari merupakan salah satu faktor yang dapat membunuh bakteri Mycobacterium tuberculosis pada TB Paru. Kondisi bangunan yang berada di pemukiman padat yang saling berdempetan sehingga menghalangi pencahayaan masuk ke dalam rumah tidak menembus sampai dalam ruangan. Penelitian yang dilakukan oleh Butarbutar, 2018 menyatakan bahwa 
semakin baik tingkat sanitasi lingkungan maka semakin rendah pasien TB Paru.

Sebagai langkah pencegahan penularan penyakit TB masyarakat dapat memperbaiki kondisi fisik lingkungan rumah khususnya dalam penambahan ventilasi di dalam rumah agar dapat memperlancar sirkulasi udara. Ventilasi rumah dapat dibuat dengan adanya jendela atau ventilasi atap. Masyarakat dapat membuka jendela dan pintu, menyalakan kipas jendela atau loteng sebagai salah satu upaya perbaikan ventilasi. Rumah dengan dinding yang saling berdempetan hendaknya membuat ventilasi udara pada atap rumah.

\section{PEMBAHASAN}

Penyakit Tuberkulosis (TB) adalah penyakit infeksi yang terjadi pada saluran pernapasan manusia disebabkan oleh bakteri berbentuk basil yang sangat kuat sehingga memerlukan waktu yang cukup lama untuk pengobatan. TB disebabkan oleh bakteri $M$. tuberculosis yang ditemukan oleh Robert Koch pada tanggal 24 Maret 1882 (Butarbutar, 2018). Bakteri M. tuberculosis bersifat patogen bagi manusia terutama diantara kaum miskin dan pengidap Human Immunodeficiency Human (HIV) yang tinggal di lingkungan urban padat, karena meningkatnya kemungkinan penyebaran melalui pernapasan dan adanya pasien-pasien yang tidak diobati. Akibat menyebar melalui pernapasan, maka mudah sekali bakteri $M$. tuberculosis berpindah kepada orang lain. Hanya melalui hembusan nafas atau batuk (Suharjo dan Girsang M, 2015).

Bakteri M. tuberculosis (basil tuberkel) merupakan bakteri batang lurus dengan ukuran sekitar 0,4 - $3 \mu \mathrm{m}$. Pada media buatan, bentuk kokoid dan filamentous tampak bervariasi dari satu spesies ke spesies lain. Basil ini tidak bergerak dan tidak membentuk spora, tidak membentuk kapsul dan apabila diwarnai sering tampak bermanik atau berbutir-butir. Satu karakteristik basil tuberkel yang menonjol adalah penampilannya yang berlilin. Zat lilin ini berperan dalam terbentuknya fase atau formasi granuloma / bintil / nodul yang terlihat pada hasil foto rontgen paru-paru penderita TB (CDC, 2016).

Gejala penyakit TB yang paling sering yaitu batuk, berupa batuk berdahak yang berlangsung selama lebih dari dua minggu, nyeri dada, sesak nafas disertai gejala sistemik (demam, malaise, keringat malam, dan anoreksia). Batuk yang diderita terkadang dapat mengeluarkan darah. Selain mengalami batuk, pengidap TB biasanya juga akan kehilangan nafsu makan sehingga mengalami penurunan berat badan dan kelelahan (Infodatin, 2018). Bakteri M. tuberculosis ketika masuk ke dalam tubuh manusia bersifat tidak aktif untuk beberapa waktu sebelum kemudian menyebabkan gejala-gejala TB. Pada kasus ini kondisi tersebut dikenal dengan tuberkulosis laten. Akan tetapi, TB yang langsung memicu gejala dikenal dengan istilah tuberkulosis aktif (CDC, 2016).

Penyakit TB ditularkan dari pasien TB yang mempunyai $\mathrm{BTA}(+)$. Pada waktu batuk atau bersin, pasien menyebarkan kuman ke udara dalam percikan sputum (droplet nuclei). Sekali batuk dapat menghasilkan hingga 3500 partikel, umumnya penularan terjadi dalam ruangan dimana percikan sputum berada pada waktu yang lama. Percikan dapat bertahan selama beberapa jam dalam keadaan yang gelap dan lembab. Ventilasi dapat mengurangi jumlah percikan, sementara sinar matahari langsung dapat membunuh kuman (Suharjo dan Girsang M, 2015).

Perumahan yang rapat dan kumuh adalah tempat yang sangat rentan terhadap penularan TB ini. Selain karena ventilasi yang minimal, sinar matahari juga tidak bisa menembus langsung sehingga kuman yang ada pada percikan dapat lebih lama dan lebih mudah tertular pada orang lain (Butarbutar, 2018). Daya penularan seorang pasien ditentukan oleh banyaknya bakteri yang dikeluarkan dari parunya. Makin tinggi derajat kepositifan BTA hasil pemeriksaan sputum, semakin tinggi risiko penularan dari pasien tersebut. Faktor yang memungkinkan seseorang terserang kuman TB ditentukan oleh konsentrasi percikan dalam udara dan lamanya menghirup udara (Muslimah, 2019).

Penyebab TB adalah bakteri yang menyebar di udara melalui semburan air liur dari batuk atau bersin pengidap TB. Pada saat penderita mengalami batuk dan bersin tanpa menutup mulut maka bakteri penyebab penyakit TB akan ditularkan melalui udara dalam bentuk percikan dahak. Apabila penderita mengalami batuk dan bersin dalam suatu ruangan yang tertutup maka akan memudahkan proses penularan TB yang akan menghasilkan 
kurang lebih 3000 percikan. TB menyebar melalui droplet nuclei penderita, sehingga setiap orang yang kontak dengan penderita TB memiliki risiko untuk terinfeksi, terutama kontak serumah penderita TB paru. Penularan penyakit TB pada kontak serumah dapat terjadi karena perilaku penderita TB paru yang menyebabkan kontaminasi bakteri TB di udara dalam rumah, seperti batuk dan bersin (Muslimah, 2019). Beberapa kelompok orang yang memiliki risiko tinggi tertular TB yaitu orang dengan sistem kekebalan tubuh yang menurun misalnya mengidap HIV/AIDS, diabetes atau orang yang sedang menjalani kemoterapi, orang yang mengalami malnutrisi atau kekurangan gizi, pecandu narkoba, perokok, dan para petugas medis yang sering berhubungan dengan pengidap TB.

Penyakit TB dapat dicegah dengan memutuskan rantai penularan yaitu dengan mengobati penderita TB sampai benar-benar sembuh serta dengan melaksanakan pola hidup bersih dan sehat, sedangkan untuk penyembuhan dengan jalan minum obat yang diberikan secara teratur, sampai dinyatakan sembuh. Seseorang yang positif menderita penyakit TB bila berobat di unit pelayanan kesehatan akan mendapat obat TB. Pemerintah menerapkan program nasional pengendalian TB strategi Directly Observed Treatment Shortcouses (DOTS) dan dilaksanakan secara nasional di seluruh Fasilitas Layanan Kesehatan (Fasyankes) terutama Puskesmas yang diintegrasikan dalam pelayanan kesehatan dasar. DOTS adalah strategi pengobatan pasien TB dengan menggunakan panduan obat jangka pendek dan diawasi langsung oleh seorang pengawas yang dikenal sebagai Pengawas Menelan Obat (PMO). Pengobatan TB dengan strategi DOTS ini merupakan satu-satunya pengobatan TB yang saat ini direkomendasikan oleh organisasi kesehatan sedunia (WHO) karena terbukti paling efektif (Dirjen P2\&PL Kementerian Kesehatan RI, 2011).

Lingkungan yang kumuh dan padat akan membuat penularan TB berlangsung cepat. Maka dari itu lingkungan yang sehat serta kebersihan makanan dan minuman sangat perlu untuk dijaga, diantaranya dengan tidak meludah di sembarang tempat, menggunakan tempat yang tertutup untuk menampung dahak, tidak membuang dahak di sembarang tempat, dan menerapkan perilaku hidup bersih dan sehat (tidak merokok, menjemur kasur dan tikar secara teratur, ventilasi udara serta sinar matahari yang baik, dan sebagainya) (Kementerian Kesehatan RI, 2016).

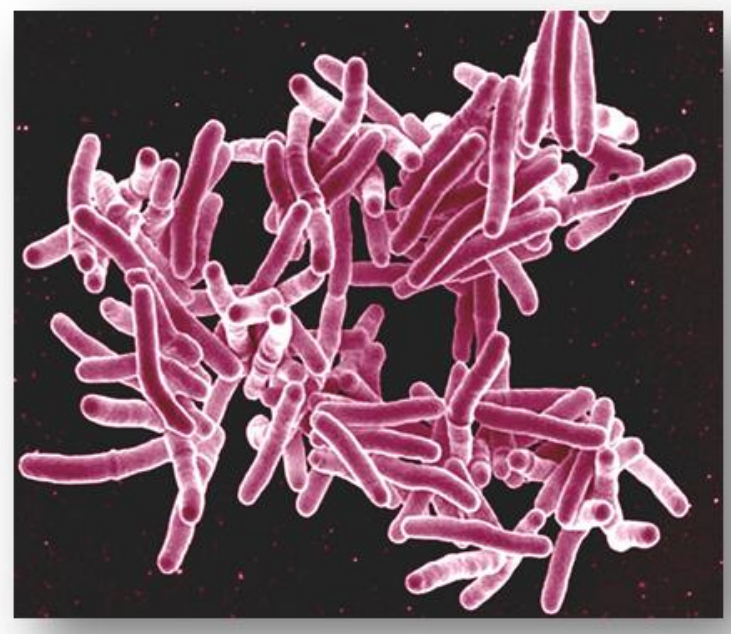

\section{Gambar 2. Bakteri penyebab penyakit Tuberkulosis (TB) Mycobacterium Tuberculosis (CDC, \\ 2016)}

\section{SIMPULAN}

Faktor lingkungan rumah yang terdiri dari pencahayaan, kelembapan, kondisi atap, dinding dan lantai signifikan berhubungan dengan kejadian penyakit Tuberculosis dan kepadatan hunian menjadi faktor yang paling Jurnal Ilmu Kedokteran Dan Kesehatan, Volume 7, Nomor 4, Oktober 2020 berpengaruh terhadap kejadian penyakit TB (Budi et al, 2018).

\section{SARAN}

Kepada Kementerian Kesehatan RI dan dinas kesehatan kabupaten/kota 
disarankan untuk meningkatkan penemuan penderita TB dan memberikan bimbingan konseling secara intensif dengan mempertimbangkan variabel sosiodemografi rumah tangga. Penyuluhan secara berkala kepada masyarakat tentang pencegahan penyakit TB juga perlu ditingkatkan agar pemberantasan penyakit TB dapat berhasil. Diperlukan pula pemantauan khusus dari pemerintah setempat tentang keadaan fisik rumah masyarakat serta pendekatan khusus seperti pendekatan keluarga untuk menyebarkan informasi mengenai pencegahan penyakit Tuberkulosis (TB).

\section{DAFTAR PUSTAKA}

Asrijun. (2018). Pengaruh Kondisi Fisik Rumah dengan Kejadian Penderita Tuberkulosis (TB) Paru. UNM Environmental Journals. 2(1):6-10.

Azhar K dan Perwitasari D. (2014). Kondisi fisik rumah dan perilaku dengan prevalensi TB paru di Propinsi DKI Jakarta, Banten dan Sulawesi Utara. Media Penelitian dan Pengembangan Kesehatan.23(4):172-81.

Budi IS, Ardillah Y, Sari IP, Septiawati D. (2018). Analisis Faktor Risiko Kejadian penyakit Tuberculosis Bagi Masyarakat Daerah Kumuh Kota Palembang. Jurnal Kesehatan Lingkungan Indonesia. 17(2):87-94.

Butarbutar MH. (2018). Hubungan Perilaku dan Sanitasi Lingkungan dengan Pasien TB Paru. Journal of Borneo Holistic Health. 1(1):51-61

Badan Pusat Statistik. (2009). Survei Sosial Ekonomi Nasional (SUSENAS) Tahun 2009. Jakarta: BPS

Centers For Disease Control and Prevention (CDC). (2016). Laten Tuberculosis. Infection: A Guide For Primary Health Care Providers. Available

https://www.cdc.gov/tb/topic/basic s/signsandsymptoms.html
Dirjen P2\&PL Kementerian Kesehatan RI. (2011). Terobosan Menuju Akses Universal, Strategi Nasional Pengendalian TB di Indonesia 20102014. Jakarta: Kementrian Kesehatan Republik Indonesia.

Janan M. (2019). Faktor-faktor Risiko yang Berhubungan dengan Peningkatan Prevalensi Kejadian TB MDR di Kabupaten Brebes tahun 2011-2017. Jurnal Kebijakan Kesehatan Indonesia. 8(2):64-70

Kementrian Kesehatan RI. (2015). Tuberculosis: Temukan Obati Sampai Sembuh. Infodatin.. Jakarta: PUSADATIN

Kementrian Kesehatan Republik Indonesia. (2016). Pencegahan dan Pengendalian Penyakit (P2P) Tahun 2016. Jakarta: Kementrian Kesehatan RI

Kementrian Kesehatan RI. (2018). Tuberculosis: Temukan Obati Sampai Sembuh. Infodatin. Jakarta: PUSADATIN

Muslimah DDL. (2019). Keadaan Lingkungan Fisik dan Dampaknya pada Keberadaan Mycobacterium Tuberculosis: Studi di Wilayah Kerja Puskesmas Perak Timur Surabaya. Jurnal Kesehatan Lingkungan. 11(1):26-33

Riskesdas. (2018). Hasil Utama Riset Kesehatan Dasar. Kementrian Kesehatan Republik Indonesia. 1100.

Suharjo dan Girsang M. (2015). Hubungan Faktor Sosial Demografi Terhadap Kejadian Tuberkulosis Menurut Stratifikasi Jenis Kelamin di Jawa Tengah. Jurnal Ekologi Kesehatan. 14(1):48-59

WHO. (2017). Global Tuberculosis Report. Geneva: World Health Organization

WHO. (2019). Global Tuberculosis Report. Geneva: World Health Organization

Versitaria, U, H. dan Kusnoputranto, $\mathrm{H}$. (2011). Tuberkulosis Paru Di Palembang, Sumatra Selatan. 5(5) 